\title{
Women and Entrepreneurship: Food Security Strategy
}

\author{
Dwia Aries Tina Pulubuhu ${ }^{1}$, Seniwati $^{2}$, Husain Abdullah ${ }^{3}$, Muhammad Sabranjamil Alhaqqi $^{4}$ \\ \{dwiatn@unhas.ac.id, seniwati@unhas.ac.id,hus_mks@yahoo.com, bram.alhaqqi@unhas.ac.id\} \\ Sociology Department, Social and Political Sciences Faculty Hasanuddin University, Jl.Perintis \\ Kemerdekaan km.10, Makassar, Indonesia ${ }^{1}$, \\ International Relations Department, Social and Political Sciences Faculty Hasanuddin University, \\ J1.Perintis Kemerdekaan km.10, Makassar, Indonesia ${ }^{2,3}$, \\ Management Department, Economics and Business Faculty Hasanuddin University, Jl.Perintis \\ Kemerdekaan km.10, Makassar, Indonesia ${ }^{4}$
}

\begin{abstract}
The purpose of this article is to analyze the extent of skills possessed by rural communities, especially women in conducting entrepreneurial activities. Therefore, the research team provided information on the importance of entrepreneurial activities and improving community skills in processing natural products through a three-day workshop. Participants who attended the workshop activities such as village officials, community leaders, and women who were directly involved in entrepreneurship activities. The article builds a model for ensuring food security through entrepreneurship activities. The research team assisted the village community in processing and utilizing natural products, especially bananas, pineapples, and black rice. During the mentoring activities, the village community, especially village women can make and process bananas, pineapple, and black rice into dodol. The research team also taught village women how to pack products and how to market these products. The results of this activity concluded that women who want to build villages in ensuring food security must have skills in processing natural products and have the initiative to become an entrepreneur. Women entrepreneurship activities support rural economic empowerment. Women and young women who participate continue to increase in entrepreneurship activities. Women entrepreneurship has a positive impact on the social and economic sectors of the family.
\end{abstract}

Keywords: Women, Entrepreneurial Activities, Food Security, Skills, Natural Products.

\section{Introduction}

There are several reasons why women want to be entrepreneurs such as want to have their own business so they can be independent; women can produce a better economy so that they can support the family economy, have more creative thoughts in providing solutions to problems faced, have high self-confidence, have leadership skills, think more efficiently and effectively in planning, more flexible in managing time, having skills in balancing business and personal affairs, having better knowledge of business and entrepreneurship[1]. Women entrepreneurs will be able to manage to still have plenty of time for their families because they have flexible 
time. They can also schedule meetings for meetings, surveys, serving customers or dropping customer orders.

The study aims to share information with rural communities, especially women, about the importance of entrepreneurs. The research team also taught the public about the use of technology as a form of innovation that is important in facilitating processing work. The concept of innovation is closely related to entrepreneurship to create a new product that is ready to be marketed [2]. Creativity will create a product that is different from other products.

Innovation in entrepreneurship can make a company survive and sustainable. Entrepreneurs who have innovation will have the ability to look for opportunities, connect with other parties and can take advantage [3]. Innovative products are products with high creativity from innovators. Innovators have a big role to play because they have a clear vision in advancing entrepreneurship activities.

This research identifies natural resources owned by the Cenrana Village area, especially those that have great potential to be marketed in other areas. This study also identifies the problems faced by women entrepreneurs. There are a lot of natural resources in Cenrana Village but they are not processed properly because the community does not have the creativity, ideas, skills and work models. Research is useful for governments, non-governmental organizations and development agencies in making policies and strategies related to food security strategies because women 's empowerment interventions can support the family economy so that households vulnerable to food insecurity can decrease[4]. Entrepreneurship among rural women is one approach that can be used in raising awareness of rural women to support village development, especially in ensuring food security. Initiative and respect from the village community will accelerate the development process in progress.

\section{Methods}

This research was conducted in Cenrana Village, Kahu Subdistrict, Bone District, South Sulawesi Province. This research was carried out from July to November 2019. Bone Regency is located east of the provincial capital of South Sulawesi. The area of Bone Regency is 4,559 $\mathrm{km} 2$. The Regency has 27 districts, 44 villages and 328 villages. The method was carried out in the form of a field survey for one week, interviews for three weeks, Focus Group Discussion (FGD) for one week, three days workshops and assistance to women for three months. Interviews were conducted with several community leaders, women and young women who were directly involved with entrepreneurial activities, and the village head. The FGD involved women and young women who were directly involved in entrepreneurial activities, village officials and community leaders. The people involved in the workshop activities are the implementation team from campus, village women who are active in entrepreneurial activities, village officials, and community leaders.

The implementation team gave a lecture on the importance of entrepreneurial activities, leveraging natural resources, and improvement of skills in processing and utilizing bananas, pineapple and black rice. Cenrana village was chosen as a research site because many villages have natural resources that are not properly treated. The village head has created women's groups. Village funds from the central government are not well managed due to lack of community skills and knowledge, especially women in processing natural products. 


\section{Results}

The most natural resources in Cenrana Village are bananas, jackfruit and black rice. Cenrana Village is located in Kahu District, Bone District, South Sulawesi Province, Indonesia. Bone District has a strategic position in the economy, especially trade and services because it is located on the East coast of South Sulawesi. Administratively, Bone District has 27 sub-districts, 333 villages and 39 sub-districts. The area of Bone Regency is around 4,559 km2. The district is bordering with Wajo and Soppeng Regencies in the North, Bone Bay in the West, Sinjai and Gowa Districts in the South, and Maros, Pangkep and Barru Districts in the East [5]. This district consists of lowlands, beaches and mountainous regions. This condition makes banana, black rice, and jackfruit plants thrive.

The research team taught women's groups about processing bananas, black rice, and jackfruit into food that is not only consumed but can also be marketed to supports the village's economic activities. Processing banana, black rice and jackfruit plants also supports food diversification which is nationally initiated by the Head of the Food Security Agency (BKP) of the Ministry of Agriculture Hendridi. Food diversification is also known as from farm to table[6]. Food diversification motivates people to process food ingredients into processed products that are ready for sale. The role of women is substantial in food processing, especially in the process of production, handling and preparation of food. This condition occurs a lot in rural areas which main livelihood is subsistence agriculture [7]. Cenrana Village is one of the subsistence areas of agriculture.

The banana plant is one of the plants that can thrive in tropical regions with low and high levels. Residents in Cenrana Village plant bananas in the yard, gardens and fields that are no longer used. The roots of a banana plant cannot be submerged in water because it will rot, so this plant cannot grow where there is a lot of water. People plant bananas because bananas can grow in all seasons, both wet and hot. Banana has a lot of fiber, so it is good for people who are on a strict diet. Before this research was conducted, bananas were generally processed by frying or making traditional food pallu butung or pallu golla. Food is only consumed at the level of the household.

The research provides motivation to the community in conducting entrepreneurs through the use of bananas, jackfruit, and black rice. Banana has a source of complete nutrition and high vitamin content. Processing bananas to the maximum, the results can be sold and bring benefits to the family economy. Banana will undergo a process of maturation. During the ripening process, the sugar content in the fruit will increase the water content and will produce a distinctive aroma. This condition will cause bananas to break quickly if they are not immediately processed [8]. One of the uses of bananas is be snacks such as dodol.

Banana dodol can be used as an entrepreneurial effort by women's groups. Banana dodol is one way to extend the shelf life of the fruit. During the workshop and mentoring, the research team taught how to make banana dodol. The processing of banana dodol will affect the products produced. In addition, the packaging process is also very influential in the processing of banana dodol because it will provide a neat and unique appearance. One promotion carried out by the community is by offering friends, food stores in the area of Cenrana Village and Kahu District, and families.

The research team also taught women's groups to process jackfruit into dodol. Jackfruit dodol is made from ripe jackfruit to get the distinctive aroma of the fruit. One way to fertilize jackfruit dodol is to use brown sugar or granulated sugar which is then processed traditionally by using a large stove and also modernly by using a non-stick pan. Jackfruit dodol is one of the 
businesses that has good prospects to be developed by women's groups in Cenrana Village because jackfruit is widely planted by residents in this region.

The involvement of women in entrepreneurs, especially the processing of jackfruit, black rice, and banana is one form of empowerment of women. Empowerment is one of way to develop agriculture because the population can become agro-biodiversity. Empowering women's groups is one of the means to support rural development and agriculture, especially in maintaining food security. The social and economic impacts of this activity include an increase in women's participation in supporting the family's economy and helping the family's social status into a prosperous family.

Female entrepreneurship is important in village development activities. The activities of village women during their time as an entrepreneur provide benefits in the social and economic sectors which indirectly have a positive impact on the global economy. Therefore, the activities of rural women participating in entrepreneurial activities are one solution to support an economy that is experiencing a crisis. The integration of village women in building village economies is a necessity. The village head and his officials support the activities of female entrepreneurship by providing funding assistance in the process of packing and marketing. The role of the government in supporting women entrepreneurs is needed to achieve village development goals and ensure food security.

Cenrana Village is one of the villages that receives financial assistance from the state budget (APBN). This village fund aims to support the implementation of development and empowerment of village communities. The village head of Cenrana provides financial assistance to women entrepreneurs to improve village public services, strengthen the village economy, reduce development disparities between villages, and provide strengthening of village communities. Women's involvement in entrepreneurship activities will support the creative economy sector. The creative economy sector can encourage an increase in the number of workers. Before the activity of utilizing jackfruit, bananas, and black rice into snacks, women generally in this village had no activities. The involvement of women and young women into creative economic actors helped create innovation because of increased understanding of the use of technology. This entrepreneurial activity benefits the village because it creates a small business that is able to provide employment and encourage the growth of the rural economic sector.

\section{Conclusions}

The research activity of entrepreneurship has an economic and social impact on the village community. The economic impact felt by female entrepreneurs is their increased income and ability to create innovation as a food producer. The social impact obtained by female entrepreneurs is the improvement of the family's social status in the community because the family is able to guarantee food security. After the workshop was completed, the community, especially the women's group, had great motivation in making dodol of jackfruit and banana. They also have a brand for the product. The skills and knowledge possessed by women's groups can support their entrepreneurial activities. Skills owned by village women influence their decision to participate in entrepreneurship activities. The involvement of women in entrepreneurial activities will support the economy of their families through local food utilization. The use of 
bananas and jackfruit will make people not consume carbohydrates continuously but also other foods that have a source of protein and vitamins.

Officials and village heads provide support for village funds as capital to increase productivity and competitiveness in entrepreneurship activities. The contribution of entrepreneurship activities to the village economy continues to increase because the number of women and young women involved in these activities also continues to increase. Entrepreneurial activities support economic empowerment as one of the objectives of using village funds.

Limitation study of this research is only limited to one village. For future research, researchers can do it in a wider area. Future research needs to examine the challenges and problems faced by women during their entrepreneurial activities. It is also necessary for the entrepreneurial characteristics to be examined for more detail in sharing information with stakeholders and women's groups.

\section{References}

[1] Xavier, S. Roland, Ahmad, S. Zamberi, M. Nor, Leilanie, Yusof, Mohar: "Women Entrepreneurs: Making A Change from Employment to Small and Medium Business Ownership." Economic and Finance." 4. 321-334. (2012) Doi: 10.1016/S2212-5671(12)00347-4.

[2] Global Entrepreneurship Monitor (GEM): Global Report 2017/18. The Global Entrepreneurship Research Association (GERA) (2018)

[3] Bessant, John and Tidd, Joe: Managing Innovation. UK: John Willey (2013)

[4] Sharaunga, Stanley, Mudhara, Maxwell, and Bogale, Ayalneh: "The Impact of 'Women's Empowerment in Agriculture' on Household Vulnerability to Food Insecurity in the KwaZuluNatal Province." Forum for Development Studies. 42(2): 195:223. (2015) DOI: 10.1080/08039410.2014.997792.

[5] Badan Pusat Statistik Kabupaten Bone: Sosial dan Kependudukan (Social and Population). Sulawesi Selatan: Badan Pusat Statistik. (2018).

[6] P., Melisa Riska: Diversfikasi Pangan di Sulawesi Selatan Diperluas (Food Diversification in South Sulawesi is Expanded)." Republika.co.id. Retrieved from https://www.republika.co.id/berita/ekonomi/makro/17/11/15/ozg9rc382-diversifikasi-pangan-disulawesi-selatan-diperluas on 31 July 2019.

[7] Galiè, Alessandra: "Empowering Women Farmers: The Case of Participatory Plant Breeding in Ten Syrian Households.” Journal of Women Studies. 34(1): 58-92. DOI: 10.5250/fronjwomestud.34.1.0058 (2013)

[8] Eriyana, Elvis, Syam, Husain and Jamaluddin: "Mutu Dodol Pisang Berdasarkan Substitusi Berbagai Jenis Pisang (Musa Paradisiaca) (Quality of Banana Dodol Based on Substitution of Various Types of Banana).” Jurnal Pendidikan Teknologi Pertanian. 3: 34-41 (2017)

Acknowledgments. We would like to thank the village head and staff of the Cenrana Village office who provided the facilities during the workshop in the form of rooms and consumption. Thanks also to groups of village women who enthusiastically participated in the workshop. This research received funding from Hasanuddin University in the Community Service Program (PKM) for the 2019 budget. 